Article

\title{
Spousal intimacy, type of antiretroviral drug and antiretroviral therapy adherence among HIV patients in Bandung, Indonesia
}

\author{
Safitri Fadilla Wardhani, 1,2 Sri Yona ${ }^{3}$ \\ ${ }^{1}$ Faculty of Nursing, Universitas Indonesia, Depok, West Java; ${ }^{2}$ Balai Besar Kesehatan Paru Masyarakat \\ Bandung, Bandung, West Java; ${ }^{3}$ Department of Medical Surgical Nursing, Faculty of Nursing, Universitas \\ Indonesia, Depok, West Java, Indonesia
}

\begin{abstract}
Background: Antiretroviral Therapy (ART) has been proven effective in reducing the mortality rates among People Living With HIV/AIDS (PLWH). However, poor adherence to ART may result in treatment failure. Few studies examine the relationship between spousal intimacy, type of ART and ART adherence. This study aimed to investigate the association between spousal intimacy, type of ART and antiretroviral therapy adherence among PLWH in Bandung, Indonesia.

Design and Methods: A cross-sectional study was conducted involving 115 adult PLWH who were receiving ART at least for 6 months in RSUD Kota Bandung, they were selected with a consecutive sampling. The data were analyzed using chi-square test.

Results: The majority of PLWH (61.74\%) reported had high level of spousal intimacy, about 93.91\% PLWH used first line of ART, and $88.69 \%$ had high adherence in consuming ART. Spousal intimacy had a significant relationship to antiretroviral adherence ( $\mathrm{p}$ value $<0.001$ ) and type of ART ( $\mathrm{p}$ value: 0.031 , OR: 7.35 ) significantly associated with antiretroviral adherence.

Conclusions: PLWH who have high levels of spousal intimacy also have high levels of antiretroviral adherence. PLWH on firstline ART were 7.3 times more adherent on ART.
\end{abstract}

\section{Introduction}

Globally ART was successful in decreasing about $48 \%$ the mortality rate caused by HIV-AIDS, ART known well as a therapy that can improve quality of life for PLWH. ${ }^{1}$ However, the effectiveness of ART affected by adherence to consume ART routinely and continuously throughout their lives. Good adherence to ART treatment lead the increased number of CD4, prevented the opportunistic infection and suppressed the viral load. ${ }^{1,2}$

In contrast to such global success, the mortality rate in Indonesia from HIV/AIDS has been increasing in line with the number of new cases finding of HIV/AIDS. The problem is largely due to low ART adherence levels, which have not reached the target established by Indonesia's Ministry of Health. ${ }^{2}$ Although 96,69\% PLWH in Indonesia receiving ART, unfortunately $22.89 \%$ among them lost to follow up or dropping out of their ART treatment. ${ }^{2}$ The low levels of ART adherence in several regions in Indonesia were related to low self-efficacy, depression, and stigma experienced by PLWH. ${ }^{3,4}$

Another studies found that ART adherence is also influenced by health service providers, peer support, and family support. ${ }^{5}$ The previous studies found that intimacy or spousal closeness can improve PLWH's physical function and health behavior. ${ }^{6,7,8}$ In addition, ART adherence also associated with the type or regiment of ART consumed. ART regimens divided between first-line regimens that have high efficacy and low toxicity and second-line regimens with higher toxicity and higher pill-burden. ${ }^{9}$ Several previous studies found that PLWH who received first-line ART had better adherence than those given second-line ART. ${ }^{10}$

Therefore, the aim of this study was to identify the relationship between spousal intimacy, type of ART and ART adherence.

\section{Design and Methods}

This cross-sectional study involved 115 respondents who attend the outpatient unit in RSUD Kota Bandung, Bandung, Indonesia. They were recruited using consecutive sampling technique. Inclusion criteria in this research were married adult PLWH who had received ART for at least six months.

This research was conducted in March until April 2019. Received ethical approval from the Faculty of Nursing Universitas Indonesia Ethics Committee (No.98/UN2.F12.D/HKP. 02.04/2019). Demographic features of participants were collected by a demographic questionnaire including age, gender, education, employment, duration of treatment and type of ART and marital status.

Level of spousal intimacy was measured by the Personal Assessment of Intimacy in Relationships (PAIR) questionnaire. ${ }^{11}$ It was modified and translated into Indonesian. Modified PAIR consist of 18 items, the first six items assessed emotional intimacy,

Significance for public health

Improving antiretroviral therapy (ART) adherence among people living with HIV/AIDS. is significant for public health. Good adherence to ART has been shown to reduce the mortality rate due to HIV/AIDS and also reduce the rate of HIV transmission. The use of single table of ART, first-line ART and spousal intimacy may relate with ART adherence. Health care provider should recognize of the risk of lower ART adherence when patient had multidrug ART and low social support from their spouse. In additional, it may also be beneficial to encourage patients to link with HIV support group and engange with family, particularly with spouse. 
the next six items assessed social intimacy and the last six items assessed sexual intimacy. These items were answered on 5 likert scale ranging from 1 (disagree) to 5 (strongly agree). To measure spousal intimacy level, researcher categorized high intimacy and low intimacy based on mean score (mean=68.67), if total score $>$ 68.67 was categorized as high intimacy and if the total score < 68.67 was categorized as low intimacy. Morisky Green Levine Scale (MGLS) Indonesian version questionnaire used to measured scale of ART adherence. ${ }^{12}$ Measurement scale of MGLS assessed with total score between $0-4$, indicated high adherence if total score was 0 , moderate adherence if total score was 1-2 and low adherence if total score was 3-4. All instruments were valid and reliable, Cronbach's alpha for PAIR (0.81) and MGLS (0.7).

Descriptive analysis was used to describe demographic (age, gender, educational level, employment, duration of treatment and type of ART). Bivariate analysis, chi-square test used to measure the relationship between spousal intimacy and antiretroviral therapy adherence and the relationship between type of ART and ART adherence.

\section{Results}

Table 1 shows the majority of respondents were 18-35 (60.87\%), female $(52.17 \%)$, employed $(81.73 \%)$, and graduated from secondary school (56.52\%). Most of the respondents had been receiving ART for $1-5$ years $(60 \%)$ and were in the first line of receiving antiretroviral drugs (93.91\%). Of the 115 respondents, $71(61.74 \%)$ reported high levels of intimacy with their spouses, and $102(88.69 \%)$ had high levels of ART adherence. Most of the respondents $(61.73 \%)$ felt high levels of sexual intimacy with their partners. This was followed by $59.14 \%$ of respondents who felt social intimacy with their partners and $27.83 \%$ of respondents who felt emotional intimacy with their partners.

Table 2 shows the bivariate analysis, based on a chi-square test the analysis demonstrated a significant relationship between spousal intimacy and ART adherence ( $p$ value: 0.000 ). The respondents who reported high levels of intimacy also had high levels of antiretroviral adherence. The analysis also show that type of ART was significantly associated with ART adherence ( $p$ value: 0.031 , OR:7.3). Respondents who received first-line ART were 7.3 times more adherent to treatment than those receives second-line ART.

\section{Discussion}

This study evaluated about the adherence on ART among PLWH in Bandung Indonesia. The proportion of females was slightly greater than that of males. It means that more women had
HIV test in outpatient clinic in the hospital. This finding is similar with Irmayati,Yona and Waluyo' study (2019) in Lampung found that among who were HIV positive, women's awareness about taking an HIV test is greater, because women feel the risk of contracting HIV from their spouses if the latter were known to be PLWH. ${ }^{13}$

Mostly, respondents had jobs that allowed them to pay for all their expenses, including their medication. The medicine consumed by most PLWH in Bandung is first-line ART, Atrivla. Atrivla is single tablet fixed dose, complete ART regimens, Efavirenz (NNRTI), Emtricitabine (NRTI) and Tenofovir (NRTI), this tablet usually take once daily.

This single tablet fixed dose was considered as the effective treatment strategy to decrease pill burden, with minimal side

Table 1. Demographic characteristics of respondents $(n=115)$.

\begin{tabular}{|c|c|c|}
\hline Variable & Frequency & Percentage (\%) \\
\hline $\begin{array}{l}\text { Age } \\
\begin{array}{l}18-35 \\
36-50 \\
>50\end{array}\end{array}$ & $\begin{array}{c}70 \\
45 \\
0\end{array}$ & $\begin{array}{c}60.87 \\
39.13 \\
0\end{array}$ \\
\hline $\begin{array}{l}\text { Gender } \\
\text { Male } \\
\text { Female } \\
\end{array}$ & $\begin{array}{l}55 \\
60\end{array}$ & $\begin{array}{l}47.80 \\
52.17\end{array}$ \\
\hline $\begin{array}{l}\text { Education } \\
\text { Low } \\
\text { Middle } \\
\text { High }\end{array}$ & $\begin{array}{l}12 \\
65 \\
38\end{array}$ & $\begin{array}{l}10.43 \\
56.52 \\
33.04\end{array}$ \\
\hline $\begin{array}{l}\text { Employment } \\
\text { Employed } \\
\text { Unemployed } \\
\end{array}$ & $\begin{array}{l}94 \\
21\end{array}$ & $\begin{array}{l}81.73 \\
18.26\end{array}$ \\
\hline $\begin{array}{l}\text { Antiretroviral therapy duration } \\
6 \text {-11 months } \\
1-5 \text { years } \\
>5 \text { years }\end{array}$ & $\begin{array}{l}14 \\
69 \\
32\end{array}$ & $\begin{array}{l}12.17 \\
60.00 \\
27.82\end{array}$ \\
\hline $\begin{array}{l}\text { Type of ART } \\
\text { First line } \\
\text { Atripla (single tablets regiment) } \\
\text { Duviral+nevirapine } \\
\text { Duviral+efavirenz } \\
\text { Second line } \\
\text { Duviral+aluvia }\end{array}$ & $\begin{array}{c}108 \\
65 \\
25 \\
1 \\
7 \\
7\end{array}$ & $\begin{array}{c}93.91 \\
56.52 \\
21.73 \\
15.65 \\
6.10 \\
6.10\end{array}$ \\
\hline $\begin{array}{l}\text { Spousal intimacy } \\
\text { Low } \\
\text { High }\end{array}$ & $\begin{array}{l}44 \\
71\end{array}$ & $\begin{array}{l}38.26 \\
61.74\end{array}$ \\
\hline $\begin{array}{l}\text { ART adherence } \\
\text { High adherence } \\
\text { Moderate adherence } \\
\text { Low adherence }\end{array}$ & $\begin{array}{c}102 \\
13 \\
0\end{array}$ & $\begin{array}{c}88.69 \\
1.31 \\
0\end{array}$ \\
\hline
\end{tabular}

Table 2. Relationship between spousal intimacy and type of ART with ART adherence.

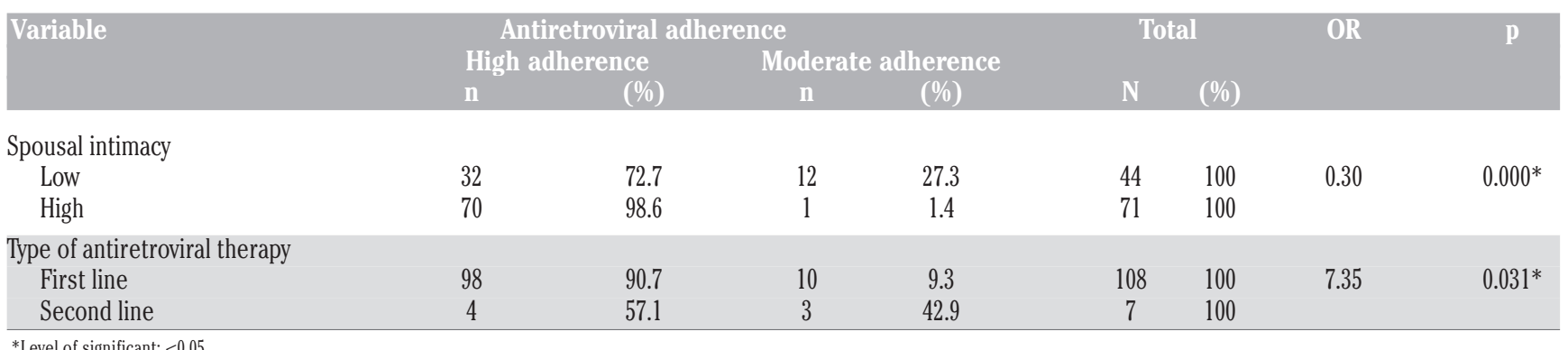


effect. ${ }^{14,15}$ In addition, The high rate of opportunistic TB infections in Bandung, Indonesia makes Atrivla, consist of Efavirenz, the right choice for PLWH who receive rifampicin therapy because the hepatotoxicity effect of Efavirenz is less than Nevirapine and it is associated with more successful virological outcomes. ${ }^{14,15}$ Many previous studies found that no significant reduction in Efavirenz plasma concentrations with Rifampicin-based tuberculosis treatment co-administration. ${ }^{16}$ Therefore this first line regimen can be tolerated by the body and can increase the CD4 cell count and suppress the incidence of resistance. ${ }^{17}$ This study found that PLWH on second-line ART had lower adherence. The low proportion of PLWH who received second-line treatment in Bandung indicated a high rate of success in the first-line ART treatment.

This study revealed high levels of intimacy by most respondents. Among Indonesians, marital status and religion are apparently two important identities. ${ }^{18}$ The motivation to maintain spousal intimacy encourage PLWH to adhere to ART treatment, moreover the religious and cultural values of Indonesian society encourage each partner to always be loyal each other even in sick conditions. ${ }^{6,19}$ The persistence of the marital relationship between partners of PLWH is a form of acceptance from both parties, so that even in conditions of HIV infection, the couples can maintain their levels of intimacy.

The analysis showed that spousal intimacy was significantly associated with the levels of adherence to ART. This suggests that these married couples share their emotional and physical support with their spouse: as a result, these respondents have higher levels of adherence to ART. A similar study from Jakarta found that all former female drug users who were HIV positive had intimate relationships with their spouses. ${ }^{20}$ In addition, these women received support from their spouses to recover from drug addiction. Their support could be emotional support, financial support, and/or physical support, such as accompanying their wives to go to a methadone support system. Most of the married PLWH consider that the physical and psychological conditions of PLWH are not a problem and do not interfere with marital relations; this is evidenced by the high level of marital satisfaction in PLWH couples. $^{21}$

Indonesia's ART adherence is still below 95\%. This current study found that the majority of PLWH who receive ART have high adherence $(88 \%)$. This result is contrary to a previous study in Lampung-Indonesia in which only $47 \%$ of respondents adhered to their medication. Several factors may contribute to this low rate of ART adherence. For example, stigma towards PLWH still exists in Indonesia. Ismail et al. found that women who become HIVinfected from their husbands still face social stigma from their families and therefore tend not to access health care services. ${ }^{22}$ In addition, low education levels lead to a lack of knowledge about the risk of transmission. This is in line with previous study by Irmayati, Waluyo, and Yona that women with lower education have less access to have health education, particularly about HIV transmission. ${ }^{13}$ This study found that the majority PLWH in Bandung had middle to high education levels, so they had better knowledge to maintain their ART adherence.

The high awareness of PLWH to visit health services was influenced by support system by the spousal. The majority of respondent were accompanied by their spouse when they visit health care service. Several studies also mention that spousal intimacy is also proven to influence health behavior, including health assistance-seeking behavior, adherence to treatment regimens, and increased well-being. ${ }^{23,} 24$

Based on the assessment of three intimacy domains, the majority of respondents felt high levels of sexual intimacy. High levels of sexual intimacy affect ART adherence. Specifically, PLWH who already feel sexually intimate will try to maintain their physical condition by regularly taking ART to avoid opportunistic infections and prevent HIV transmission to their partners. Therefore, motivation to maintain sexual intimacy with partners plays a role in increasing adherence to ART treatment. ${ }^{6}$

Social intimacy is the second domain perceived by respondents. This assessment of social intimacy domains illustrates how PLWH interact with partners and colleagues or friends in their social environments. The high levels of social intimacy felt by PLWH indicate the high levels of social support obtained by PLWH. Social support for PLWH can be in the form of motivational support from partners to maintain a healthy lifestyle and reminders from PLWH to always take ART on time. For PLWH on ART treatment, having a supportive partner is an important aspect of their support system. Such support helps retention and adherence by motivating PLWH, reminding them to take medicine every day, reducing the fear associated with care, and helping them financially to remain in care. ${ }^{25}$

In addition, social support can also be obtained from peer community support. Couples with high levels of social intimacy have more effective peer support groups. According to information obtained by researchers at the time of the preliminary study, most PLWH who were treated at RSUD Kota Bandung were members of the peer support community. In these communities, PLWH could remind each other to take ART on time to increase adherence.

Social support for PLWH can have a positive effect on mental health. ${ }^{26}$ When PLWH have a source of social support during stress, they will seek social support as a positive coping strategy and avoid looking for negative coping strategies such as avoiding or being emotional. In contrast to the results obtained in this research, a high level of social information was not followed by a high level of emotional intimacy. In this study, it was found that the level of emotional intimacy was the intimacy domain that respondents felt the least. The gap between this research and previous research is due to the side-effects of ART treatment. The majority of respondents in this research had high levels of ART adherence, so it was possible for them to experience high levels of neuropsychological side-effects. This is similar to the findings of several other studies: neuropsychiatric complications that can arise in 50\% of people living with HIV after ART treatment can be in the form of dizziness, nightmares, insomnia, anxiety, and depression. ${ }^{14,26,27}$ The emergence of several neuropsychiatric disorders could affect the emotional levels of PLWH.

Based on the type of antiretroviral consumed, the majority of respondents received first-line ART and we found that most of PLWH used atripla as the first-line ART. Similar to Alfian, Ibrahim $\&$ Rafiyah that the majority of PLWH in Bandung received firstline ARV treatment. ${ }^{28}$ This is also according to the results of study in Lampung, Indonesia which found that most PLWH received atrivla as the first-line ART. ${ }^{4}$ Atripla is a line 1 fixed-dose combination ARV in the preparation of 1 tablet taken once a day. One atripla tablet contains $600 \mathrm{mg}$ evafirenz (NNRTI), $200 \mathrm{mg}$ emtricitabine (NRTI) and $300 \mathrm{mg}$ tenofofir (NRTI). According to the Indonesian Ministry of Health a combination of fixed-dose or fixed-dose combination (FDC) first line is considered to be the most effective combination of drugs with minimal side effects and easy to consume because it is only taken once a day so that it can increase ART adherence. ${ }^{14}$ The first-line ART well tolerated by the body, increased CD4 cell count and suppress the incidence of resistance, with the result that supported PLWH to become more adherent on ART treatment. ${ }^{17}$ Moreover this study found small propor- 
tion of respodents received second-line ART, with a combination of Duviral + Aluvia. According to the Indonesian Ministry of Health second-line ART consumed by the PLWH who have already failed on the first line treatment, as measured by the CD4 cell count, HIV viral load or clinical features. ${ }^{14}$ The low proportion of PLWH who received second-line treatment in the city of Bandung indicated a high rate of success in first-line ARV treatment.

This study shows that the higher level of spousal intimacy, the better level of adherence to ART. Therefore, future intervention that encourage and support partner involvement could improve ART adherence among HIV heterosexual couple in Indonesia.

Based on this study, it can be concluded that spousal intimacy has a higher association with levels of adherence to ART. Although some variables such as stigma may interfere with adherence to ART, the higher levels of spousal intimacy may positively influence partners, through increasing motivation to adhere with ART. In a developing country such as Indonesia, having adequate support from a partner plays a crucial role in HIV treatment. This significant impact of relationships needs to be further integrated into clinical practice and other behavioral interventions, particularly for married couples.

Correspondence: Sri Yona, Department of Medical Surgical Nursing Department, Faculty of Nursing, Universitas Indonesia , Jalan Prof. Dr. Bahder Djohan, UI Depok Campus, West Java 16424, Indonesia. Tel. +62.21.78849120 - Fax. +62.21.7864124.

E-mail: sriyona@ui.ac.id

Key words: Adherence; antiretroviral; spousal intimacy; type of ART.

Contributions: SFW, concept and design, undertook the data collection, analysis and interpretation of data, drafting and revision manuscript; SY, concept and design, data analysis, proofread manuscript, critical revision of manuscript, final approval

Conflict of interest: The authors declare there are no conflicts of interests.

Acknowledgments: This study was supported by the Universitas Indonesia Hibah PITTA B 2019 Number NKB - 0489 / UN2.R3.1/ HKP. $05.00 / 2019$. The authors would like to thank all respondents who have been involved in this study, and all HIV clinic staff at RSUD Kota Bandung.

Ethics approval and consent to participate: This study was approved by The Ethics Committee of Faculty of Nursing Universitas Indonesia (No. 98/UN2.F12 D/HKP.02.04/2019). All participants signed the informed consent.

Availability of data and materials: Available from the corresponding author at reasonable request.

Conference presentation: This final manuscript has been presented at $7^{\text {th }}$ Virtual Biennial International Nursing Conference, Faculty of Nursing, Universitas Indonesia on September $24^{\text {th }}$, October $30^{\text {th }}$, November $16^{\text {th }} 2020$.

Received for publication: 4 June 2020 .

Accepted for publication: 26 February 2021

${ }^{\circ}$ Copyright: the Author(s), 2021

Licensee PAGEPress, Italy

Journal of Public Health Research 2021; 10(s1):2336

doi:10.4081/jphr.2021.2336

This work is licensed under a Creative Commons Attribution

NonCommercial 4.0 License (CC BY-NC 4.0).

\section{References}

1. UNAIDS [Internet]. UNADIS data 2017. Accessed on: 2018 Nov 7. Available from: https://www.unaids.org/en/resources/ documents/2017/2017 data book

2. Ministry of Health Republic of Indonesia. [Laporan perkembangan HIV-AIDS \& infeksi menular seksual (IMS) triwulan IV tahun 2017 (Report on the progress of HIV-AIDS \& sexually transmitted infections (STI) for the fourth quarter of 2017)].[In Indonesian]. Report No.: PM.02.02/III/766/2017. Jakarta: Ministry of Health Republic of Indonesia; 2018. Available from: https://siha.kemkes.go.id/portal/perkembangan-kasus-hiv-aids_pims

3. Andini S, Yona S, Waluyo A. Self-efficacy, depression, and adherence to antiretroviral therapy (ART) among Indonesian women with HIV. Enferm Clin 2019;29:687-90.

4. Nurfalah F, Yona S, Waluyo A. The relationship between HIV stigma and adherence to antiretroviral (ARV) drug therapy among women with HIV in Lampung, Indonesia. Enferm Clin 2019;29:234-7.

5. Yuniar Y, Handayani RS, Aryastami NK. [Faktor-faktor pendukung kepatuhan orang dengan HIV AIDS (ODHA) dalam minum obat antiretroviral di Kota Bandung dan Cimahi (Factors supporting the adherence of people with HIV AIDS (PLWHA) in taking antiretroviral drugs in Bandung and Cimahi)].[Article in Indonesian]. Buletin Penelitian Kesehatan 2013;41:72-83.

6. Gamarel KE, Golub SA. Intimacy motivations and pre-exposure prophylaxis (PrEP) adoption intention among HIV-negative men who have sex with men (MSM) in romantic relationships. Ann Behav Med 2015;49:177-86.

7. Manne S, Badr H, Zaider T, et al. Cancer-related communication, relationship intimacy, and psychological distress among couples coping with localized prostate cancer. J Cancer Surviv 2010;4:74-85.

8. Robles TF, Slatcher RB, Trombello JM, McGinn MM. Marital quality and health: a meta-analytic review. Psychol Bull 2014; 140:140-87.

9. Lacob SA, Lacob DG, Jugulete G. Improving the adherence to antiretroviral therapy, a difficult but essential task for succesful HIV treatment-clinical points of view and practical consideration. Front Pharmacol 2017;8:831.

10. Clay PG, Nag S, Graham CM, Narayanan S. Meta-analysis of studies comparing single and multi-tablet fixed dose combination HIV treatment regimens. Medicine (Baltimore) 2015;94:e1677.

11. Schaefer MT, Olson DH. Assessing intimacy: the pair inventory. J Marital Fam Ther 1981;7:47-60.

12. Morisky DE, Ang A, Krousel-Wood M, Ward HJ. Predictive validity of a medication adherence measure in an outpatient setting. J Clin Hypertens 2008;10:348-54.

13. Irmayati N, Yona S, Waluyo A. HIV-related stigma, knowledge about HIV, HIV risk behavior and HIV testing motivation among women in Lampung, Indonesia. Enferm Clin 2019;29:546-50.

14. Ministry of Health Republic of Indonesia. [Antiretroviral use regulation no. 87 of 2014, (Nov 11, 2014)].[In Indonesian]. Available from: https://www.kebijakanaidsindonesia.net/id/ d o k u m e n - k e bi j a k a n ? t a s k = d o w n lo a d. send\&id $=645 \&$ catid $=17 \& \mathrm{~m}=0$

15. Jiang HY, Zhang MN, Chen HJ, et al. Nevirapine versus efavirenz for patients co-infected with HIV and tuberculosis: a systematic review and meta-analysis. Int $\mathrm{J}$ Infect Dis 2014;25:130-5. 
16. Borand L, Madec Y, Laureillard D, et al. Plasma concentrations, efficacy and safety of efavirenz in HIV-infected adults treated for tuberculosis in Cambodia (ANRS 1295-CIPRA KH001 CAMELIA trial). PloS One 2014;9:e90350.

17. Castro E, Recordon-Pinson P, Papuchon J, et al. First-line antiretroviral treatment outcome in a patience presenting an HIV-1/2 multiclass drug resistant infection. J Int AIDS Soc 2012;15:1-1.

18. Himawan KK, Bambling M, Edirippulige S. What does it mean to be single in Indonesia? religiosity, social, stigma, and marital status among never-married Indonesian adults. Sage Open 2018;8.

19. Eidhamar LG. 'My husband is my key to paradise.' attitudes of Muslims in Indonesia and Norway to spousal roles and wifebeating. Islam Christ-Muslim 2018;29:241-64

20. Yona S, Ismail R, Nurachmah E, et al. Gaining a "normal life": HIV-positive Indonesian female injection drug users in drug recovery. J Ethn Subst Abuse 2021;20:117-34.

21. Salahudin MI, Fitrikasari A, Soforo MAU, Julianti HP. [Perbedaan kepuasan perkawinan pada pasangan ODHA disertai dan tanpa disertai gejala depresi (Differences in marital satisfaction between PLWHA couples with and without symptoms of depression].[Article in Indonesian]. Jurnal Penyakit Dalam Indonesia 2018;5:135-40.

22. Ismail R, Voss JG, Woods NF, et al. A content analysis study: concerns of Indonesian women infected with HIV by husbands who used intravenous drugs. J Assoc Nurse AIDS C 2018;29:914-23.

23. Johnson MO, Dilworth SE, Taylor JM, et al. Primary relationship, HIV treatment adherence and virologic control. AIDS Behav 2012;16:1511-21.

24. Pietromonaco PR, Uchino B, Schetter CD. Close relationship processes and health: implications of attachment theory for health and disease. Health Psychol 2013;32:499-513.

25. Casale M, Wild L. Effects and processes linking social support to caregiver health among HIV/AIDS-affected carer-child dyads: a critical review of the empirical evidence. AIDS Behav 2013;17:1591-611.

26. Wicaksono YA, Fitrikasari A, Sofro MAU, Peni H. [Hubungan stigma dan terapi ARV dengan komplikasi gangguan psikiatri pada pasien HIV/AIDS (Relationship between stigma and ARV therapy with complications of psychiatric disorders in HIV/AIDS patients)].[Article in Indonesian]. Jurnal Penyakit Dalam Indonesia 2018;5:24-8.

27. Robertson K, Liner J, Heaton R. Neuropsychological assessment of HIV-infected populations in international settings. Neuropsychol Rev 2009;19:232-49.

28. Alfian A, Ibrahim K, Rafiyah I. The effect of the E-Patuh application on HIV/AIDS patients' adherence in consuming antiretroviral. Jurnal Keperawatan Padjajaran 2019; 7:49-57. 